UNRAM Law Review is licensed under a Creative Commons Attribution 4.0 International License, which permits unrestricted use, distribution, and reproduction in any medium, provided the original work is properly cited. p-ISSN: 2548-9267 | e-ISSN : 2549-2365, Open Access at : http://unramlawreview.unram.ac.id/index.php/ulr

\begin{tabular}{c|c|c|c|c|}
\hline Volume & Issue & Page & April & p-ISSN: 2548-9267 \\
\hline 3 & 1 & $1-6$ & 2019 & e-ISSN : 2549-2365 \\
\hline
\end{tabular}

\title{
Granting of Legal Experts as an Invention of Law Model Through Legal Research on The Criminal Justice System
}

\author{
Erdianto Effendi \\ Faculty of Law Riau University, Pekanbaru \\ Jl. Patimura No. 9 Gobah Pekanbaru 28131 \\ Telepon (0761) 22539 Faksmile (0761) 21695 \\ Laman : www.fh.unri.ac.id Email fh@unri.ac.id
}

\begin{abstract}
Invention of law activity by judge is not optimum because the judge must be rolled from a region to other region. While the judge is hoped to find the living law. This article concluded that invention law by judge should be aided by granting of legal expert in Th Criminal Justice System. Legal researcher should hoped to invent the living law in community.
\end{abstract}

Keyword: Legal Expert, Invention of Law

\section{INTRODUCTION}

What is meant by the invention of law is usually the process of legal formation by a judge, or other legal apparatus assigned to the application of general law rules to concrete legal events. In short, it can be defined as a general conceptualization process or individualization of the rule of law (das sollen) by remembering certain concrete events (das sein). ${ }^{1}$

The discovery of the law, according to Sudikno Mertokusumo there are two types:

a. The invention of Heteronomic Law is that if the judge's judicial discovery is entirely subordinate to the law, the judge merely insists that the law be applicable to its concrete event, and then the judge applies it according to the law.

b. The invention of the Autonomous Law is if the judge in his judgment is guided by his views, understanding, experience and observation or his own mind. So the judge decides a case confronted to him according to personal appreciation, without any absolute bound to the provisions of the law.

Judging from the flow in the invention of the law, there are three forms of flow: Legism (Positivism Law), Freirechbewegung and Rechtvinding (Invention of Law by Judge) consisting of the Begriffsjurisprudenz Stream, Interessenjurisprudenz, Soziologische Rechtschule. ${ }^{2}$ If in the flow of legislation the judges are fully subject to the Act, in Freirechtbewegung's flow, the judge is free and does not depend on the Law because the judge is the legislator. Rechtvinding flowis the middle ground of both, and this flow is the one adopted in Indonesia.

Article 10 and Article 5 of Law Number 48 Year 2009 regarding Judicial Power determines that a judicial institution should not refuse to examine, hear, and decide upon a case filed against it under the pretext of the law being non-existent, or less obvious but obligatory to

${ }^{1}$ Sudikno Mertokusumo. (2014), The Invention of Law, an Introduction. Yogyakarta:Cahaya Atma Pusaka.p.49.

${ }^{2}$ Achmad Rifai. Invention of Law in Progressif Law Perspective, Jakarta: Sinar Grafika. p. 31-33. 
examine and adjudicate it, So as law enforcement and justice, the judge must dig, follow and understand the values of law and sense of justice that lives in society.

Thus, judges should be given the opportunity to interact longer with the community so as to explore the sense of justice and values that live in the community in which he is in charge. On the other hand, the judges must undergo the process of rotating the term of duty from one place to another throughout Indonesia. How can a judge dive in a sense of justice and the value of a living law if he is not more than four years old in an area. In the event of any difference in value between applicable law and living law, the judge is in a dilemmatic position, whether to apply the Law of Positive Law or enforce living laws.

In the Indonesian legal system there are many differences between the positive law and the laws that live in society. As a result, many suspects, corruption suspects until convicted of corruption get public sympathy despite the fact that they have been found guilty. Even until they have been imprisoned in Penitentiary they feel not guilty. That is why the often present sight in their mass media that has been established as a suspect and even who has undergone imprisonment still feel himself innocent and remain confident to laugh freely. ${ }^{3}$

Why it happens is bec a use what the law enforcers perceive as corruption with what is perceived by those accused of corruption is a different matter. Many practices that are actually lawful (state) incorre ct and included as corrupt behavior by society are considered to be commonplace references to past habits.

Various opinions and research results reveal the causes of corruption. According to Fiona Robertson Snape as quoted by Teguh Kurniawan (2009). In the case of Indonesia itself, there are a number of analyzes that attempt to explain why corruption is so developed in Indonesia. According to Snape, there are at least three factors that point to the development of corruption, collusion and nepotism (KKN) in Indonesia, namely political factors, economic factors, and Javanese cultural factors.

In Zumi Zola (Governor of Jambi Province) case, judge decide him is guilty, but in public opinion he is no guilty. Jambi peole regard sympathy to him.

The same is true not only with corruption, but in almost all crimes. Performing logging or forest burning perceived as a crime by the state in some societies is considered an act that may be done. What is dishonorable according to state law is not necessarily blameworthy by society. ${ }^{4}$

These issues not only occur in the field of criminal law but also in the field of civil law, especially in land cases. What the legitimate public thinks, before the state becomes invalid. That is why there are so many legal issues in land cases in Indonesia. The Basic Agrarian Law provides a place for customary law enforcement, but the problem then stumbles upon which customary law can be enforced.

Mobility of inter-regional population and inter-ethnic marriages is thus speed. Regions are no longer dominated by certain ethnic groups, but are also inhabited by other ethnic groups in many areas with more populations than local ethnic populations. Heterogeneity is not only occurring in urban areas, but has also occurred in rural areas, making it very difficult to establish a customary law code that can be enforced in an area.

\section{METHOD}

The approach method used is juridical-normative, with the type of dogmatic research, the form of research prescriptive relationship law. Specification of this research is descriptivePos.

${ }^{3}$ Erdianto Effendi.( 16 April 2016), “ State Law, Opinion and Public Law Idea”, Opinion of Riau ${ }^{4}$ Ibid

2 Erdianto Effendi| Granting of Legal Experts as an Invention....... 
analytical. Methods of data collection used through library research method (library method) by testing the document materials and library materials used in this study.

Data are analyzed qualitatively-normatively, researching by way of interpreting and constructing statements contained in the statutory document. Qualitative analysis method, constructed based on secondary data in the form of theory, meaning and substance from various literatures, statutory regulations, and primary data obtained from interviews, observations and field studies, then analyzed with normality law, theory and expert opinion related, so that it can be concluded about the definition of criminal law policy related to environmental management and eradication of environmental problems in the society in the future.

\section{ANALYIS AND DISCUSSION}

\section{Dualism Formation of Indonesian Legal System}

Indonesia as a former Dutch colony followed a positive legal paradigm that became the spirit of the civil law law system. In living law Indonesian society is more suited to the common law law system. Even if based on the written positive law, written law that is recognized for centuries in Indonesian society, then the law is Islamic law written concretely and firmly in Al Qur'an and Assunnah. This is evident from the philosophy of customary law that reads the custom of jointed syarak, syarak bersendi kitabullah.

As a middle ground, Mochtar Kusumaatmadja initiated another "legal system" which was later called Developmental Law Theory which in essence acknowledged that the applicable law was still a positive law deliberately compiled by the state, but the values adopted were custom and religious values. Law is formed by taking into account the value of living in society. At a glance this is similar to the character of the school of law and culture. The law of a linear state with the religion and custom of society. Laws only institutionalize or formalize something that people believe to be law.

The idea of Mochtar Kusumaatmadja commonly referred to as the theory of development law essentially states that law can serve as a means of renewal of society which is a modification of the Roscoeu Pound concept, law as tool of social engineering and living law concept of Eugen Ehrlich.

Based on the realities of society and the cultural situation in Indonesia and the real needs of Indonesian society, Mochtar formulates the theoretical basis for the development of national law by accommodating the legal views of the two figures above and cultivating it into a concept which views law as a means of renewal, Guarantee law and order of law.

The development of national law and law as a means of development is that a positive national law which will be a social reform tool, requires renewal and coaching. The function of law in development as a means of community development is based on the assumption that the existence of order or order in the development or renewal effort is something that is desirable or even perceived (absolutely) necessary.

Another assumption contained in the legal conception as a means of development is that law in the sense of rules or rules of law can indeed function as a means or regulator in the sense of channeling the direction of human activity in the direction desired by development or renewal. ${ }^{5}$ Both functions are expected to be done by law in addition to its traditional function is to ensure the certainty and order. ${ }^{6}$ The bottom line is that while the law is made for planned purposes, it must be sensitive to the development of society and that it must be adjusted or adjusted to changing circumstances. This is according to Mochtar in line with the minds of the

\footnotetext{
${ }^{5}$ Mochtar Kusumaatmadja. (2006), "Legal Concept in Legal Development”, The Colection of Paper, Bandung:Alumni.p.88.

${ }^{6}$ Ibid
} 
people of Indonesia for example as it is contained in the Minangkabau saying that "sakali aia gadang sakali tapian baranjak". ${ }^{7}$ This means that customs change according to the state of society.

The question then is how to know whether a legal provision to be determined is in accordance with the legal consciousness of society (or the sense of community justice) and who can reveal it? Is the House of Representatives (DPR) as a representative of the people can be called as a representation of community's justice and justice? It is doubtful whether a representative body of people always really voiced the will of the people. Therefore, according to Mochtar Kusumaatmadja public legal awareness can be expressed through legal research conducted by educational and research institutions as well as individuals.

Between Pound and Erlich, suitable system for Indonesian legal system should is Erlich concept, but the way to accommodate Erlich concept, we need Pound concept about las as social control in side, and in the other side, we also need law as social engineering if we discuss to formulate law about modern developing.

Jurisprudence is an important source of legal identification, as well as the opinion of most prominent experts and law scholars in a particular branch of jurisprudence. Finally, even members of the public may even be entitled to express their opinions because eventually however the law is made for the community.

The inclusion of the role of legal experts in the formulation of legislation is through Academic Paper. According to the provisions of Article 1 number 11 of Law Number 12 Year 2011 concerning the Establishment of Legislation, Academic Paper is the text of research result or legal study and other research results on a certain problem that can be scientifically responsible for the regulation of the problem in a Draft Law, the draft of the Provincial Regulation, or the Draft of Regency / City Regulation as a solution to the problems and legal needs of the community.

The Academic Paper of a Draft Law or Draft Law is a portrait that provides an overview or explanation of various matters relating to the legislation to be established, then through the Academic Paper can be determined whether the Legislation to be established will institutionalize or formalize what Has been there and runs in the community. Thus, the academic Paper is a research product produced by the legal expert in the university.

Institutionalize or formalize the living values in society is the establishment of legislation through the bottom up process. This process is what society hopes for, while the government only acts as a facilitator. Formalize the values that exist in the community. ${ }^{8}$

\section{Invention of Law through Legal Research}

In the legal system of Indonesia, it is recognized that law is not merely a law but also a judge's decision. If in the process of legal formation (rechtforming) the jurists contribute their thoughts through academic texts of legislation, then in the process of judicial discovery of the law, the jurists should also be involved in the judicial process.

In legal practice today the involvement of legal experts in the judicial process is through the provision of expert information. Article 184 of the Criminal Procedure Code which provides the basis of the legitimacy of the presence of experts in procedural law, especially criminal procedural law, also contains academic debate. Some people believe that the presence of jurists in the trial is not necessary because law practitioners begin advocates, prosecutors and judges are also legal experts.

\footnotetext{
${ }^{7}$ Ibid

${ }^{8}$ Abdul Basyir, "Urgency Academic Paper in Forming Law to be an aspiratif and responsife law", in Jurnal IuS | Vol II | Nomor 5 | Agustus 2014 | p.294.
}

4 Erdianto Effendi| Granting of Legal Experts as an Invention...... 
On the other hand, the presence of experts from the campus becomes a necessity to explain the theoretical and philosophical matters related to the problem of legal practice being faced. Eddy OS Hiariej ${ }^{9}$ believes that the presence of jurists in the court at least for two reasons, namely First, in relation to the unevenness of the judges. Let alone on the substance of the subject matter of the trial, the things that are fundamental in the science of law are not understood. In the event of such a case, a court seeking the material truth of a legal event will lead to a misguided judiciary because of the incompleteness of the substance of the law in its entirety. Second, it should be understood that the principle of ius curia novit applies only to judges and not to investigators or public prosecutors.

In the criminal justice process, not infrequently expert information has been requested since the investigation, whether presented by the investigator or presented by the suspect. In fact, often the prosecutor's instructions to the investigator to complete a case file must be supplemented with the information of a criminal. If an expert has been presented in the investigation and a verbal process has been made by the investigator, consequently the expert must be heard in court.

With regard to not allowing the judges to dig up the legal values and sense of justice of the local community as the legislators' disagreement in extracting living values in the process of law formation, it should be that the presence of jurists in the proceedings does not merely explore the expert's capabilities in terms of With theoretical and philosophical academic ability, (judicially should the legal practitioners know more) but also at the same time explore the sociological aspects of law in a society. Unlike judges who move from one region to another, academics in college work permanently at a college in an area until he retires.

Academics in college have a wider opportunity to discover the values that live in the community in which they work. So it is fitting that the results of the research are not only published in scientific journals but can also be explained in court proceedings. According Soerjono Soekanto, empirical legal research in law includes:

- Research on legal identification

- Research on legal effectiveness

- Research on unwritten laws.

Through research with this empirical approach, legal experts can better recognize the sense of justice of the local community. With the presence of lawyers in the trial, the judges are helped to find the living laws in society to construct their decisions. Thus, it is hoped that there will be no contradiction between the living law and the applicable law.

One decision that respects customary law, according to Nyoman Serikat, is the Decision of the Supreme Court No. 984 K / Pid / 1996 dated January 30, 1996. In this decision, the panel of judges stated if the perpetrator (dader) of adultery had been sanctioned by adat or received a customary reaction by the traditional village stakeholders, where customary law was still respected and lived fertile, the demands of prosecutors must be declared unacceptable.

Another decision quoted by the Undip Professor in Semarang was the Decision of the Supreme Court No. 1644 K / Pid / 1988 dated May 15, 1991. In this decision the assembly considers someone who has committed an act that is according to living law (customary law) in the area is an act that violates customary law, namely "custom offense". The head and the traditional leaders give reaction to the adat (customary sanctions) against the perpetrator.

The customary sanctions have been carried out by the convicted person. Against the convicted person who has been subjected to a 'customary reaction' by the customary head, he cannot be brought up again (for the second time) as a defendant in a state court body (District Court) with the same charges, violating customary law, and sentenced to prison according to

\footnotetext{
${ }^{9}$ Eddy OS Hieraiej, Expert as Conviction, Kompas, 25 April 2016.
} 
the Criminal Code (Article 5 paragraph 3 letter b Emergency Law No. 1 Drt 1951). In such circumstances, the transfer of case files and prosecutors' demands in the District Court must be declared unacceptable (niet ontvankelijk verklaard).

\section{CONCLUSION}

Based on the above discussion, it can be concluded that Granting of Legal Experts as a Invention of Law Model Through Legal Research on The Criminal Justice System is needed in Law Enforcement in Indonesia as alternative model to combine the positivism and the living law.

\section{BIBLIOGRAPHY}

\section{Books}

Achmad Rifai. Invention of Law in Progressif Law Perspective. Jakarta: Sinar Grafika.

Mochtar Kusumaatmadja. (2006). “Legal Concept in Legal Development”. The Colection of Paper, Bandung: Alumni.

Nyoman Sarikat Putra Jaya, “Criminal Law in the Renewal of National Criminal Law”, Paper presented in Criminal Law and Criminology Training, orgainsed by Fakultas Hukum Universitas Lambung Mangkurat dengan MAHUPIKI, 16 - 19 Mei 2016.

Sudikno Mertokusumo.( 2014). The Invention of Law, an Introduction. Yogyakarta: Cahaya Atma Pusaka.

\section{Journal Article}

Abdul Basyir.(2014). "Urgency Academic Paper in Forming Law to be an Aspiratif and Responsife Law”, in Jurnal IuS.Vol II .Nomor 5 .

\section{Newspaper Article}

Eddy OS Hieraiej, Expert as Conviction, Kompas, 25 April 2016.

Erdianto Effendi, “State Law, Opinion and Public Law Idea”, Opinion of Riau Pos, 16 April 2016. 